\title{
Are migrants in/from emerging economies more entrepreneurial than natives?
}

\author{
Maribel Guerrero ${ }^{1,2,3}$ (D) Vesna Mandakovic ${ }^{1}$. \\ Mauricio Apablaza ${ }^{4}$. Veronica Arriagada ${ }^{5}$
}

Accepted: 16 December 2020 / Published online: 12 January 2021

(C) Crown 2021

\begin{abstract}
The academic debate in migrant entrepreneurship has mainly focused on movements from emerging economies into developed economies. Anecdotal evidence has suggested that the highest impact is generated by migrants in/from emerging economies. To extend this academic discussion in the Latin-American context, this study investigates why migrants are more entrepreneurial than natives. By adopting the human capital and the institutional approach, we theorize that individual and environmental conditions produce selection/discrimination effects in the host labour market. Consequently, these effects influence migrants' decision to become entrepreneurs. We tested our hypotheses using a sample of 13,368 adults between the ages of 18-64 based across the 16 Chilean regions. Our results showed that being a high-skilled migrant in a dynamic emerging economy is not a guarantee of success in the labour market, but it is a determinant of international and necessity-driven entrepreneurship. Several implications and a provocative discussion emerged from these findings.
\end{abstract}

Keywords Human capital · Institutional economics · Migrant entrepreneurship · Entrepreneurship quality $\cdot$ Internationalization $\cdot$ Emerging economies

GEL $\mathrm{O} 15 \cdot \mathrm{L} 26 \cdot \mathrm{O} 55$

\author{
Maribel Guerrero \\ maribel.guerrero@northumbria.ac.uk \\ Vesna Mandakovic \\ vmandakovic@udd.cl \\ Mauricio Apablaza \\ mapablaza@udd.cl \\ Veronica Arriagada \\ vaarriag@uc.cl
}

Extended author information available on the last page of the article 


\section{Introduction}

The research on migrant entrepreneurship has examined the conditions at the micro (demographics, physiological, human capital), meso (regional, networks, financial capital), and macro (regulatory frameworks, socio-economic conditions) level for a better understanding of the antecedents and the consequences of entrepreneurial initiatives developed by migrants (Dheer 2018). Moreover, particular research lines have emerged for exploring specific characteristics of minority/ethnic entrepreneurship (Waldinger et al. 1990; Chreim et al. 2018), transnational entrepreneurship (Drori et al. 2009; Elo et al. 2018), and refugee entrepreneurship (Gold 1992; Sandberg et al. 2018), among others. Despite these relevant insights, the academic debate in migrant entrepreneurship has mainly focused on the effect on entrepreneurial activity generated by individuals from emerging economies in developed countries (Dheer 2018; Grau and López 2018). Anecdotal evidence has suggested an impact on value creation, job creation and innovation generated by the migration of individuals from emerging economies into a transitional economy in Asia (Huang 2012; Skeldon 2012) or in Latin-America (John 2019).

Inspired by this gap in the literature, this paper has focused on three ongoing academic discussions. The first academic debate is related to why migrants are more entrepreneurial than host country nationals, highlighted by Vandor and Franke (2016a), Liu et al. (2019) and Sahasranamam and Nandakumar (2018). Extant studies have found that migrants are more likely to engage in entrepreneurial activities than natives in the context of high-income economies (Hart and Acs 2011; Fairlie and Lofstrom 2015; Nontenja and Kollamparambil 2018), and Roland Xavier et al. (2013) found higher entrepreneurial activity rates among migrants than among natives in the context of low-income economies. The explanation is related to the migrants' human capital that conditioned their entry into the labour market (Huang 2012; Skeldon 2012). The second academic debate is related to the role of environmental conditions in migrant entrepreneurship in emerging economies, highlighted by Brenes et al. (2018), Dheer (2018) and Krieger et al. (2018). Extant studies have found that skilled individuals from emerging economies are more likely to migrate to countries with short institutional distances (Naudé et al. 2017; Kenney 2017). Indeed, several studies have also found that favourable institutional conditions towards migration in host countries foster migrant involvement in entrepreneurship (Fitzgerald et al. 2014; Simón-Moya et al. 2014; Kenney 2017). The third academic debate is related to the quality of migrants' entrepreneurial initiatives, highlighted by Elo et al. (2018) and Saridakis et al. (2019). Riddle et al. (2010) found that, by living in different cultures, migrant entrepreneurs encounter new products/ services and customer preferences. In this vein, entrepreneurial migrants could transfer their knowledge of customer problems or solutions between nations.

Based on these academic discussions, this study investigates why migrants from/in emerging economies are more entrepreneurial than natives. By adopting the human capital and the institutional approach, we theorize that individual and environmental conditions produce selection/discrimination effects in the host labour market. Consequently, these effects, as well as the quality of their entrepreneurial initiatives, influence migrants' decisions to become entrepreneurs. We tested our proposed conceptual framework in Chile. The three main reasons that support this research setting are: (a) Chile has faced an increasing migration trend over the last decade from emerging and 
developed economies (DEM 2017). During the past 5 years, the number of migrants has doubled, transforming Chile into the first choice of destination for migrants in Latin America; (b) Chile has a stable institutional framework and a dynamic economy, which is very attractive for high-skilled Latin-American migrants (Amoros and Bosma 2014) and (c) the Chilean policymakers have adopted the 'Silicon Somewhere' model to reinforce environmental conditions that foster entrepreneurial activity (Mandakovic et al. 2015; Giest 2017). Our results showed that being a high-skilled migrant in a dynamic emerging economy is not a guarantee of success in the labour market, but it is a determinant of international and necessity-driven entrepreneurship.

Following this introduction, the paper is structured as follows: "Theory and hypotheses" section describes the theoretical foundations in migrant entrepreneurship in and from emerging economies. "Methodology" section provides a detailed description of the data collection and data analysis. "Results" section shows the insights obtained regarding our three research objectives. "Discussion" section discusses the findings in light of previous studies. The last section provides the main conclusions and implications that have emerged from this study.

\section{Theory and hypotheses}

\section{Entrepreneurship propensity}

Over the last decade, entrepreneurship literature has provided relevant insights into the over-representativeness of migrant populations in entrepreneurial activity (Stephan and Levin 2001; Wadhwa et al. 2008; Hart and Acs 2011; Fairlie and Lofstrom 2015; Kochhar 2015; Anderson and Platzer 2006; Monti et al. 2007). Only a few studies have analysed the high entrepreneurial propensity of ethnic communities in the United States (i.e., Chinese, Indian and Korean) (Anderson and Platzer 2006; Fairlie et al. 2010; Wadhwa et al. 2007), or in the United Kingdom (i.e., Asian, Indians, Pakistanis, and Bangladeshis) (Clark et al. 2017). Although there is no conclusive evidence, some studies have argued that migrants from emerging economies are more entrepreneurial than locals from developed/developing economies (Clark and Drinkwater 2000, 2016). As a result of the selection/discrimination effect of the host labour market, we assume that the entrepreneurial propensity between natives and migrants is explained by the individual and environmental conditions.

\section{Individual characteristics}

According to the theoretical foundations of human capital theory (Becker 1985), human capital is one of the most critical conditions for entry into the labour market for those who migrate from one emerging economy to another (Charles et al. 2018; Biavaschi et al. 2018). Peroni et al. (2016) find that the migrants' educational background alone is not enough to overcome the barriers associated with asymmetries of information or qualifications required by the labour market to protect the local labour force (Clemens et al. 2018). Several studies have found that the small reward for high-skilled migrants in remunerated employment explains why they choose self-employment to obtain higher income (Davidsson and Honig 2003; Constant and Zimmermann 2006). It also 
explains why only some migrants accept overqualified positions until they can save enough money to develop an entrepreneurial initiative (Paulson and Townsend 2004; Colakoglu et al. 2018). Under this assumption, skilled migrants face auto-selection due to labour market conditions in the host country (e.g., work permits, recognition/ accreditation of diplomas, protective laws for locals, etc.), increasing their probability of becoming entrepreneurs (Carlsson and Jacobson 1997; Florida 2002; Levie 2007; Sahin et al. 2007; Chaganti et al. 2008; Acs et al. 2009; Kloosterman 2010). Based on these arguments, we propose the following hypothesis:

\section{Hla. High-skilled migrants are more likely to develop entrepreneurial initiatives than nationals}

Concerning the origin of migrants, prior studies have identified that the most important source of migrant entrepreneurship is from emerging economies like Mexico, India, South America, Central America, and Korea (Kerr and Kerr 2020). Low-skilled migrants from emerging economies, particularly from Latin-America, are survivalist entrepreneurs that face significant migrant barriers in labour markets (Kloosterman and Rath 2001). Despite this typical scenario, among the individuals who decide to migrate from emerging economies to emerging economies, not only low-skilled, but high-skilled workers as well looking for a better quality of life can be found (Marvel et al. 2016; Vandor and Franke 2016b). We assume that migrants in and from emerging economies are more motivated to exploit their knowledge, skills, and cross-cultural experiences to discover/create entrepreneurial opportunities than natives (Liu et al. 2019; Guerrero 2020). Based on these arguments, we propose the following hypothesis:

H1b. High-skilled South-American migrants are more likely to develop entrepreneurial initiatives than high-skilled migrants from the rest of the world

\section{Environmental conditions}

Environmental dynamism reveals a constant renovation of the economy, society and industry which attract people motivated by entrepreneurial and innovative initiatives (Baron and Tang 2011). According to Massón-Guerra and Ortín-Ángel (2019), there is a positive relationship between a city agglomerations, amenities/infrastructures and density for stimulating entrepreneurship in Latin-American countries. Following this, Audretsch et al. (2018) and Chowdhury et al. (2018) have found a strong relationship between entrepreneurship, the quality of institutions and economic situation. Although most emerging economies are embedded in institutional voids (Bruton et al. 2008; Welter 2011; Guerrero and Urbano 2020), migrants select dynamic emerging countries with better institutional conditions than those of their home countries (Manev and Manolova 2010) to reap economic returns (Fitzgerald et al. 2014; Nontenja and Kollamparambil 2018). Based on these arguments, we propose the following hypothesis:

H2a. Host emerging economy regions with dynamic environmental conditions are more attractive for migrant entrepreneurs than emerging economy regions with non-dynamic environmental conditions 
International entrepreneurship theory recognises the influence of institutional distances on the creation of ventures between home and host countries (Verbeke and Ciravegna 2018). These institutional distances suggest that individuals/organisations develop entrepreneurial initiatives in foreign countries derived from differences/similitudes in formal (regulative) and informal (normative and cognitive) institutional environments (He et al. 2018). Moreover, the long-term relatedness between countries, that is, their cultural distance or proximity, also affects country selection (Krieger et al. 2018). Prior studies have shown the impact of environmental conditions on facilitating and inhibiting the identification of opportunities, the creation of ventures and their management by migrants (Bagwell 2018; Lin et al. 2018; Guerrero et al. 2020). In the Latin-American context, environmental dynamism reflects a higher concentration of Latin-American migrants that provide social, financial and experiential capital for starting new ventures, thereby contributing to the demand/supply side of entrepreneurship (Fairchild 2010). It is assumed that the return expected by LatinAmerican migrants motivates them to look for host countries with close cultural distance and better institutional quality than home countries. Based on these arguments, we propose the following hypothesis:

$H 2 b$. South-American migrants are more attracted by emerging economy regions with dynamic environmental conditions than migrants from the rest of the world

\section{Entrepreneurship quality}

According to Acs (2006), the quality of entrepreneurship is strongly linked to the social/economic contribution or return produced by each type of entrepreneurship. Over the last decade, several studies have recognised the need for matching the type of entrepreneurship (necessity vs. opportunity) and the quality of entrepreneurship (productive vs. unproductive) (Belda and Cabrer-Borrás 2018; Chowdhury et al. 2018). Migrant entrepreneurship literature has identified patterns of opportunitydriven entrepreneurship in China (e.g., individuals who identify an opportunity from their home country and go to the host country to exploit it) as well as necessity-driven entrepreneurship in Latin-American countries (e.g., individuals who were auto-selected/discriminated by the host labour market and created a new venture motivated by the necessity linked with unemployment) (Liu et al. 2019). Given the lack of information on migrant entrepreneurship in emerging economies, a proxy to understand the quality of migrant entrepreneurship could be associated with high-skills. If high-skilled migrants from emerging economies are linked to the creation of new venture by necessity, it implies that the labour market in the host emerging economy does not have the capacity to offer employment for high-skilled migrants. Assuming that the creation of necessity-driven entrepreneurship is motivated by the selection/discrimination of highskilled migrants in the labour market of the host emerging economies, we propose the following hypothesis:

H3a. High-skilled migrants (e.g., South-American countries) are more likely to develop entrepreneurial initiatives motivated by necessity than opportunity 
Prior studies have found that entrepreneurial migrants tend to outperform local entrepreneurs (Terjesen and Elam 2009; Pruthi and Mitra 2018). A plausible explanation is that migrant entrepreneurs are looking for entry into similar home markets to obtain greater returns (Griffin-EL and Olabisi 2018; Moghaddam et al. 2018). Entrepreneurial migrants have access to international networks (created by family, other migrants) that represent a competitive advantage over natives (Neville et al. 2014; Sui et al. 2015; Morgan et al. 2017). An interesting example is that of transnational diasporas composed of migrants and their descendants who establish entrepreneurial activities spanning the national business environments of their countries of origin and countries of residence (Drori et al. 2009; Riddle et al. 2010; Riddle and Brinkerhoff 2011). Assuming the likelihood of migrants entering international markets is due to the market conditions of the host emerging economy, we propose the following hypothesis:

H3b. High-skilled migrants (e.g., South-American countries) are more likely to have an international orientation than national and migrants from the rest of the world

\section{Methodology}

\section{Sample}

We use data from the 2016 and 2017 Chilean Global Entrepreneurship Monitor (GEM) Adult Population Survey (APS). Our analysis includes 16 regions and covers 13,368 individuals. GEM is a rich, internationally harmonised source of individual-level information about the motives and ambitions of entrepreneurs. ${ }^{1}$ We specifically use these two waves because the questionnaire incorporates questions about the nationality of the respondents and allows us to identify the migrant population. Data for regionyear variables were collected from the Chilean Central Bank.

\section{Measures}

Table 1 shows the descriptive statistics of the variables used in our study.

\section{Dependent variables}

To test our hypotheses, we explored the likelihood of an individual living in Chile to engage in entrepreneurial activities. Dependent variables used are from the GEM survey, where we consider an "entrepreneur" any individual engaged in an earlystage entrepreneurial activity (TEA). The other two variables are motivational derivations of the first: necessity- and opportunity-based entrepreneurial activity. The fourth and final dependent variable used is internationally born entrepreneurs. In all cases, individuals were coded as " 1 " if they met the described criteria, otherwise, the respondents were given the value of " 0 ". More concretely, the variables are defined

\footnotetext{
${ }^{1}$ For more details on the GEM project's data-collection design and implementation, see Reynolds et al. (2005).
} 
Table 1 Descriptive statistics

\begin{tabular}{lcccc}
\hline Variable & Mean & Std. Dev. & Min & Max \\
\hline TEA & 0.270 & 0.444 & 0 & 1 \\
Necessity-based entrepreneurship (TEA NEC) & 0.242 & 0.428 & 0 & 1 \\
Opportunity-based entrepreneurship (TEA OPP) & 0.746 & 0.435 & 0 & 1 \\
International entrepreneurship (INT) & 0.476 & 0.499 & 0 & 1 \\
Migrant & 0.030 & 0.171 & 0 & 1 \\
South American Migrant (SAM) & 0.024 & 0.153 & 0 & 1 \\
Rest of the World Migrant & 0.005 & 0.071 & 0 & 1 \\
High-skilled & 0.324 & 0.468 & 0 & 1 \\
Age & 39.220 & 13.181 & 18 & 64 \\
Knowing other Entrepreneurs & 0.431 & 0.495 & 0 & 1 \\
Opportunity Recognition & 0.491 & 0.500 & 0 & 1 \\
Self-Efficacy & 0.619 & 0.486 & 0 & 1 \\
Fear of Failure & 0.314 & 0.464 & 0 & 1 \\
Female & 0.499 & 0.500 & 0 & 1 \\
Log GDP region & 9.763 & 1.273 & 6.603 & 11.027 \\
\hline
\end{tabular}

as follows: Early-stage entrepreneurial activity, a variable based on the life-cycle of the entrepreneurial process. This process covers nascent entrepreneurs who have taken some action to create a new business in the past year, but have not paid any salaries or wages in the last three months, and the owners/managers of businesses that have paid wages and salaries for more than three months but fewer than 42 months (Bosma et al. 2008). Opportunity-based entrepreneurship, this variable includes individuals who voluntarily create a new venture to pursue perceived business opportunities. These individuals have a "pull" motive into entrepreneurship, such as gaining independence or increasing personal or family income, challenge, status, and recognition (Reynolds et al. 2005). Necessity-based entrepreneurship: individuals who declare themselves to be engaged in a necessity-based entrepreneurial activity if they have no better options for work. These individuals have a "push" motive into entrepreneurship, due to a lack of other labour opportunities. International entrepreneurship: nascent entrepreneurs with a strong international orientation including individuals with more than $25 \%$ of revenue from international markets (Reynolds et al. 2005).

\section{Independent variables}

Based on the literature review (Vandor and Franke 2016a, b; Liu et al. 2019), the main independent variable is Migrants. According to the GEM APS survey, this variable takes the value of 1 if the respondent reports that he or she was born in a country that is not Chile. To capture the effect of migrants from emerging economies with close cultural and institutional distance (Marvel et al. 2016; Krieger et al. 2018), the variable Migrant was disaggregated into South-American Migrant and Migrants from the rest of the world (Kloosterman and Rath 2001; Kerr and Kerr 2020). To capture the effect of the key individual selection/discrimination condition in the host emerging economy 
(Constant and Zimmermann 2006; Peroni et al. 2016; Clemens et al. 2018), we use the variable High-skilled. This variable is a dummy variable differentiating those individuals who completed graduate studies from those who did not. The skill-enhancing effect of education influences entrepreneurial activity: highly educated entrepreneurs will recognise more opportunities (Kwon and Arenius 2010; Autio and Acs 2010; Crecente-Romero et al. 2018). To capture the effect of the key environmental selection/ discrimination condition in the host emerging economy (Manev and Manolova 2010; Bagwell 2018; Lin et al. 2018; Verbeke and Ciravegna 2018; He et al. 2018), we used the Log GDP region (lagged) as the approximation of the attractiveness of dynamic regions for migrants. Concretely, this variable is measured by the Logarithm of the Gross Domestic Production of the region where the entrepreneur declares to work (Massón-Guerra and Ortín-Ángel 2017, 2019). We use this variable lagged one period to avoid potential causality problems.

\section{Control variables}

As we are exploring the migrant entrepreneurship phenomenon at the individual level (Bosma 2013), we introduced the following control variables in our model: Female, this variable takes the value of 1 if the respondent is female and 0 if the respondent is male. Cross-country studies on entrepreneurial behaviour have shown that early-stage entrepreneurship varies significantly by gender (Bosma et al. 2008; Stephan et al. 2015). Age and Age-squared: age is an important factor in entrepreneurial activity (Levesque and Minniti 2006). With younger individuals showing higher levels of entrepreneurial activity, age-squared is also regularly included to capture any non-linear effects (Estrin et al. 2013). Knowing other entrepreneurs: this variable is used as a proxy of the individuals' social capital, as respondents indicated they knew someone who had started a business in the two years preceding the survey; this approach is consistent with previous studies (Sahasranamam and Nandakumar 2018). Opportunity Recognition: respondents were asked if in the next six months they thought there would be good opportunities for starting a business in the area where they live. Ardichvili et al. (2003) argue that identifying and selecting the right opportunities for new businesses are among the most important abilities of a successful entrepreneur'. Self-Efficacy is a variable which measures whether the individual perceives that he or she has the knowledge, skill, and experience required to start a new business (Arenius and Minniti 2005). Fear of Failure: respondents were asked whether fear of failure would prevent them from starting a business. Fear of failure is an important component of the risk attached to starting a new business (Arenius and Minniti 2005).

\section{Empirical model}

To assess empirical support for our hypotheses, we run a logistic regression model, mainly because the dependent variables are binary. Hypotheses 1 and 2 estimate the probability of an individual to engage in an entrepreneurial activity. It takes into consideration the whole sample, individuals that define themselves as entrepreneurs as well as those that do not (13,368 obs). Further estimations concerning hypotheses 3 only consider the individuals that are entrepreneurs, because they make reference to the quality and expectations of the entrepreneurs. Therefore, the size of the sample is 
smaller (3800 obs). Table 2 shows the correlation matrix, the first matrix the correlations for all the sample and the second matrix for the case of individuals that are entrepreneurs. The dataset does not suffer from severe collinearity issues. The variance inflation factor (VIF) statistics do not exceed 10, a critical threshold regarding the severity of multicollinearity (O'Brien 2007).

\section{Results}

The results of the logistic regression models are presented in Table 3, where the odds ratios are reported. ${ }^{2}$

With regard to the migrant status, the likelihood of engaging in entrepreneurial activity increases if the individual is a migrant, as indicated in Model $1(\beta=1.694$, $p<0.01$ ). This result is consistent with previous literature which shows that the incidence of migrant entrepreneurship is higher among the migrant population compared to native born. Model 2 introduces the interaction between high levels of education and migrant status (Hypothesis 1a). The positive effect that being a migrant has on entrepreneurial activity shown above, increases if the migrant has higher levels of human capital, a result of the selection discrimination effect in the host country $(\beta=1.510$, $p<0.1$ ). We split migrants in two groups, the first group is defined as South American migrants and the second group contains those from the Rest of the World. The evidence presented in Model 3 shows that the interaction term between the variable High-skilled and each of the migrant groups results is only significant and positive in the case of South American migrants $(\beta=1.438, p<0.91)$. This result supports Hypothesis H1b.

To test the hypotheses concerning dynamic environmental conditions and migrant entrepreneurship, we divided the regions in Chile as a function of their economic dynamism, using the regional GDP per capita as a proxy. Thus, we generated two groups: a region in the group with high GDP per capita takes the value of 1 , and a region in the group of lower dynamism takes the value of 0 . To test Hypothesis $2 a$, we included an interaction term between migrant and economic dynamism. We find evidence (reported in Model 4) that supports $\mathrm{H} 2 \mathrm{a}$; in more dynamic regions, migrants are more likely to engage in entrepreneurial activity $(\beta=1.915, p<0.05)$. With regard to $\mathrm{H} 2 \mathrm{~b}$, the interaction term was not significant, therefore we did not find evidence to support that South American Migrants are more attracted to start a venture in dynamic regions (see Model 5).

Our last set of hypotheses was associated with the quality and expectations of migrant entrepreneurs. Model 7 shows that South American migrants have a higher propensity to start an entrepreneurial activity when motivated by opportunity $(\beta=2.460, p<0.01)$, but this effect is attenuated when they have higher skills $(\beta=0.219, p<0.01)$. The opposite happens when evaluating necessity-based entrepreneurial activity (Model 8); being a South American migrant makes starting a necessity based entrepreneurial venture less likely $(\beta=0.427, p<0.05)$, but the propensity increases if the migrant has higher skills $(\beta=4.386, p<0.01)$. Concerning international orientation, all migrants (South-American or from the rest of the world) have a higher likelihood with respect

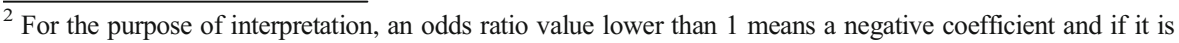
higher than 1 the coefficient is positive.
} 


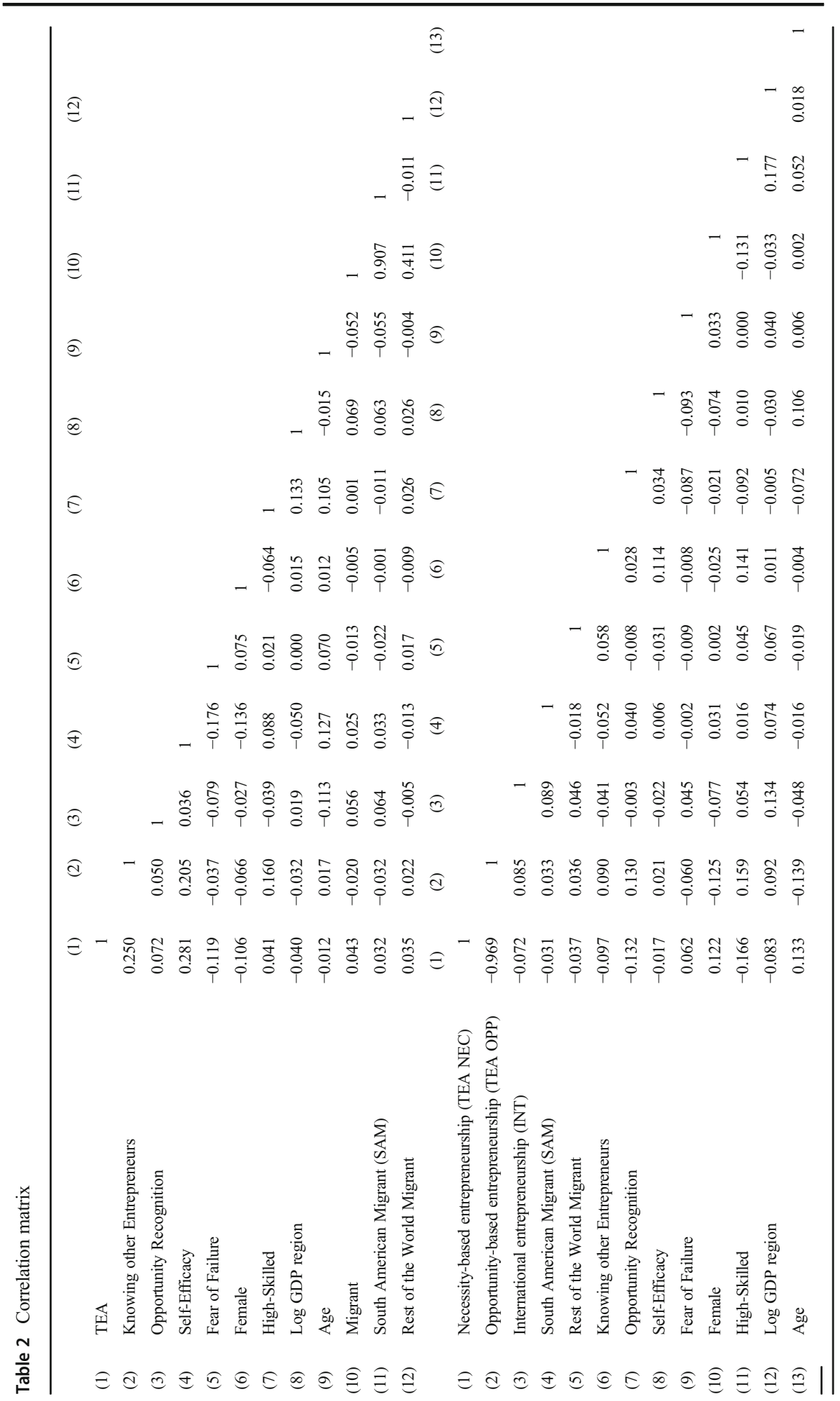


to host country nationals of creating internationally oriented ventures (Model 9). As formulated in hypothesis $3 \mathrm{~b}$, migrants are more able to have access to international networks, and in particular South-American migrants have closer cultural and geographical distances $(\beta=2.887, p<0.01)$.

As a robustness check we calculated all the previously estimated models with a parsimonious ordinary least squares estimation method (Table 4). We observe that the significance of the estimated coefficients is consistent with the estimations obtained in Table 3, making our results robust through different estimation methods. Table 5 shows another robustness exercise where we use a proxy for high skill; instead of tertiary education (high skills) we used social capital, both variables are correlated and it can be considered as an external capacity. The significance and direction of the effect of these results are similar to the ones found in Table 3.

\section{Discussion}

\section{Academic implications}

This paper examines the phenomenon of migrant entrepreneurship in the context of emerging economies. By focusing on the migration received by Chile from SouthAmerican countries, our results show three patterns. First, the evidence obtained confirms the patterns observed in previous studies that migrants are more entrepreneurial than host nationals (Anderson and Platzer 2006; Wadhwa et al. 2007; Fairlie et al. 2010; Clark and Drinkwater 2000, 2016; Clark et al. 2017). Given the nature of emerging economies (e.g., higher bureaucracy and legal issues associated with work permits, recognition/ accreditation of diplomas), the particularity is that the host labour market selects/ discriminates both high and low skilled migrants (Guerrero 2020). In comparing Chile with the rest of South-American countries, the Chilean government has extensive experience in the implementation of policies and programmes which support the creation of new business and attract foreign entrepreneurial talent (e.g., Programme Start-up Chile). However, the labour market still faces several shortcomings as well as certain particularities that help to protect the local labour force. As a result, our findings contribute new insights to academic findings regarding why migrants are more entrepreneurial than host country nationals (Vandor and Franke 2016b; Liu et al. 2019; Sahasranamam and Nandakumar 2018), concretely those in and from an emerging economies context. Specifically, we find that migrants are keener to start an entrepreneurial activity than locals, but high-skilled migrants from South American countries are more likely to engage in entrepreneurial activity when motivated by necessity.

Second, although the interaction between migrants and regional GDP was not achieved, the conclusion from this exercise confirmed a strong relationship between migration and the dynamism of a region. These findings are consistent with previous studies that highlighted the positive relationship between city agglomerations and entrepreneurial density (Audretsch et al. 2018; Massón-Guerra and Ortín-Ángel 2019). In the case of emerging economies, migrants from emerging economies expect to obtain a better return than in their home countries. Therefore, dynamic economic regions are very attractive for achieving the migrants' economic objectives. However, for migrants from emerging economies, the main characteristics determining the 


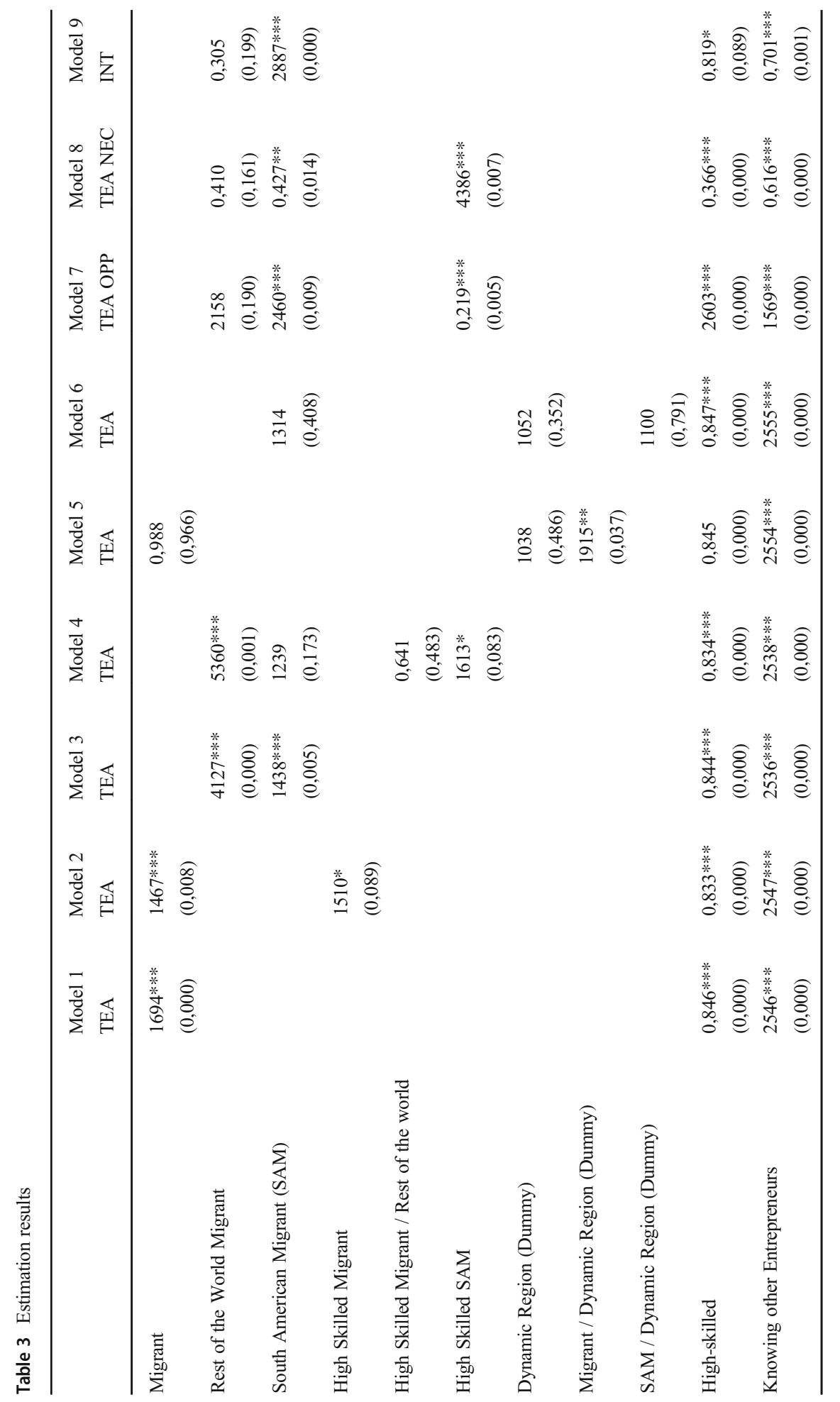




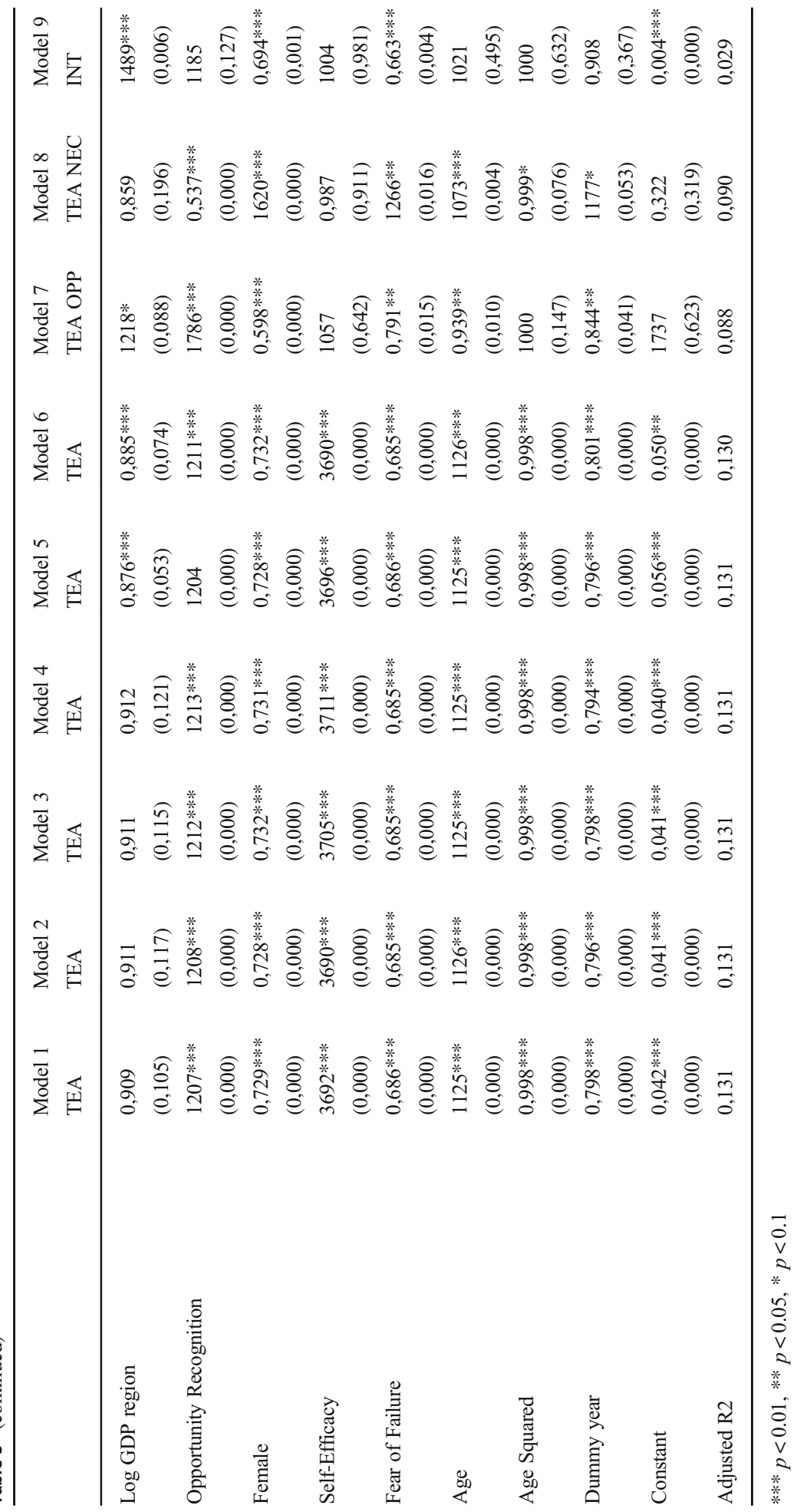


selection of the host country are close cultural distance and better institutional quality than home countries (He et al. 2018). As a result, we contribute to the academic debate regarding the environmental selection and discrimination conditions that help or hinder migrant entrepreneurship in emerging economies (Brenes et al. 2018; Dheer 2018; Krieger et al. 2018).

Third, our findings also provide interesting insights into the quality of migrant entrepreneurship; for example, our results show that migrant entrepreneurs are more likely to engage in internationally oriented ventures. In line with previous studies, the findings have shown that low-skilled migrants are associated with lower entrepreneurial quality and vice versa (Belda and Cabrer-Borrás 2018; Chowdhury et al. 2018). However, exploring the context of emerging economies provides new evidence about the importance of high-skilled migrants. More concretely, our findings show that being a high-skilled migrant in a dynamic emerging economy is not a guarantee of success in the labour market, but it is a determinant of international and necessity-driven entrepreneurship. As a result, we also contribute to the debate regarding the quality of migrants' entrepreneurial initiatives and their international orientation (Elo et al. 2018; Saridakis et al. 2019).

\section{Managerial implications}

Our study has implications for policymakers and business leaders. In emerging economies that are looking to improve their productivity, like Chile, our findings show that being a high-skilled migrant is not a guarantee of success in the labour market. As a result of a an inefficient allocation of resources, a highly qualified labour force is being pushed to start an entrepreneurial activity (necessity-based) because of the lack of opportunities in the labour market. Policies should be designed to address this issue, in line with encouraging the integration process of migrants in the labour force. This implies recognising the institutional voids in the migration and labour policy that impede the integration of these potential workers, generating potential stratification of the migrant population (McGovern 2012). For instance, the lack of a professional skills recognition system or the use of inadequate requisites for obtaining a visa hinders the insertion of high-skilled migrants into the labour market. Moreover, not only should labour insertion of high-skilled migrants be promoted, but a flexible system to accommodate migrant entrepreneurship should be developed as well.

\section{Limitations and future research}

Our study has limitations that offer opportunities for future research. First, we focus on the Chilean case as a host country, mainly due to the nature of our data. It would be interesting to explore the same hypothesis with other emerging economies from Latin America or other continents. A cross-country analysis could generalize the discussion by taking advantage of the heterogeneity of institutional contexts. To address this limitation, we encourage further research to expand the analysis with richer information about the regional dynamics; in this specific case more information needs to be generated at a regional, or country level to expand the macro-level indicators of context. Second, our study seeks to explain individual-level decisions regarding entrepreneurial activity, but as shown in the study, the phenomenon is complex and it brings into the 


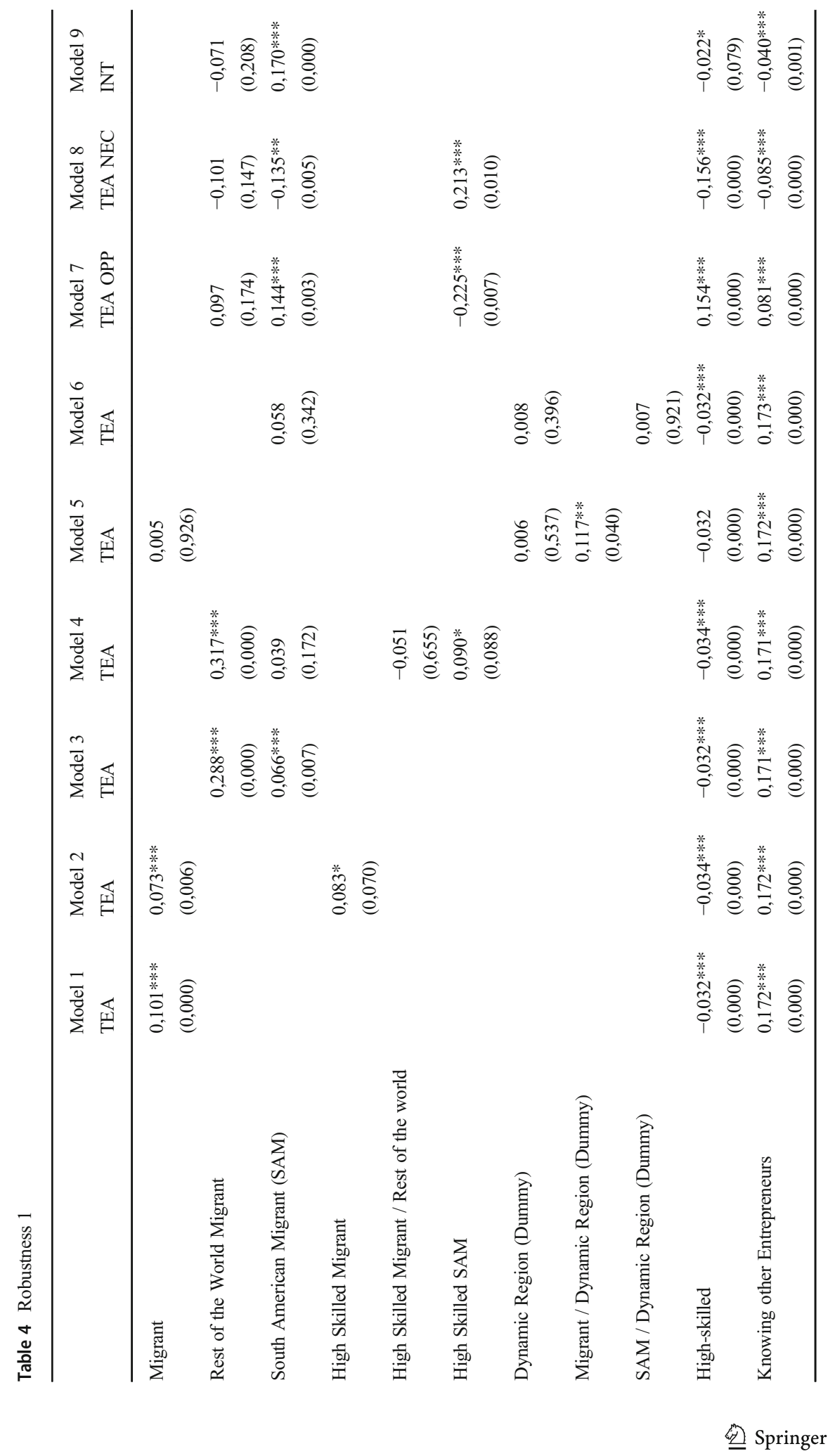




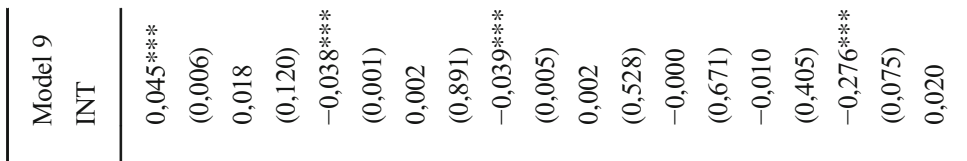

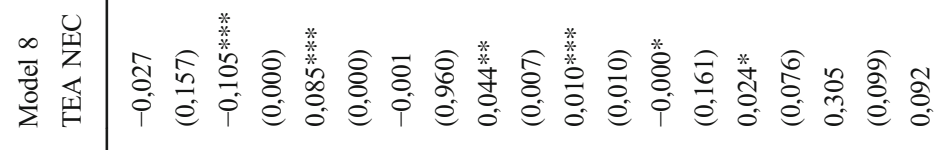

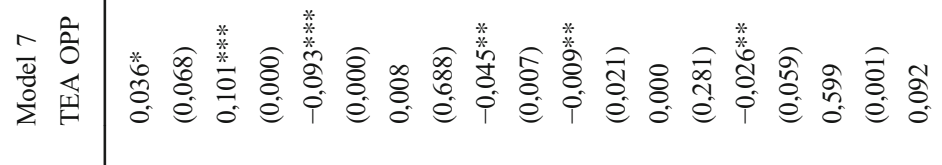

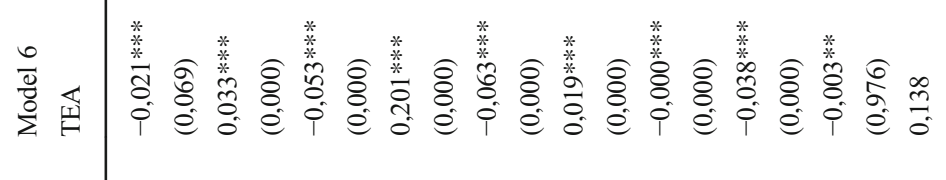

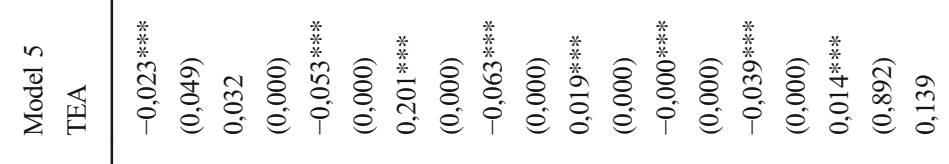

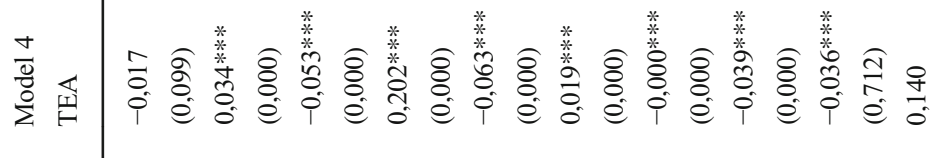

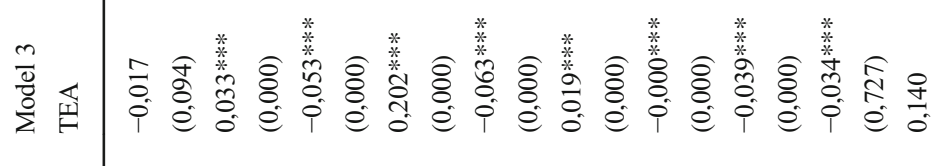

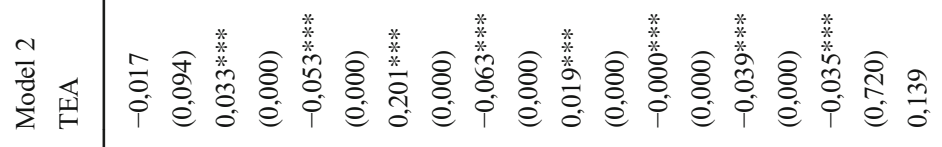

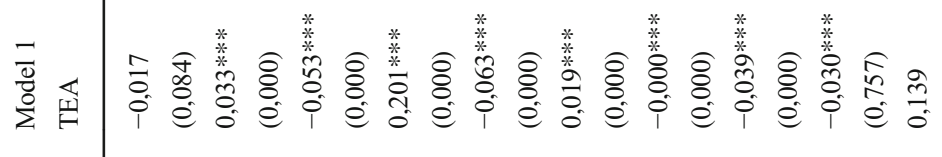


Table 5 Robustness 2

\begin{tabular}{|c|c|c|c|c|c|c|c|}
\hline & $\begin{array}{l}\text { Model } 1 \\
\text { TEA }\end{array}$ & $\begin{array}{l}\text { Model } 2 \\
\text { TEA }\end{array}$ & $\begin{array}{l}\text { Model } 3 \\
\text { TEA }\end{array}$ & $\begin{array}{l}\text { Model } 4 \\
\text { TEA }\end{array}$ & $\begin{array}{l}\text { Model } 5 \\
\text { T E A } \\
\text { OPP }\end{array}$ & $\begin{array}{l}\text { Model } 6 \\
\text { T E A } \\
\text { NEC }\end{array}$ & $\begin{array}{l}\text { Model } 7 \\
\text { INT }\end{array}$ \\
\hline Migrant & $\begin{array}{l}1694 * * * \\
(0,000)\end{array}$ & $\begin{array}{l}1288 * * * \\
(0,113)\end{array}$ & & & & & \\
\hline Rest of the World Migrant & & & $\begin{array}{l}4127 * * * \\
(0,000)\end{array}$ & $\begin{array}{l}1942 * * * \\
(0,346)\end{array}$ & $\begin{array}{l}2161 \\
(0,189)\end{array}$ & $\begin{array}{l}0,409 \\
(0,160)\end{array}$ & $\begin{array}{l}0,305 \\
(0,199)\end{array}$ \\
\hline $\begin{array}{l}\text { South American Migrant } \\
\text { (SAM) }\end{array}$ & & & $\begin{array}{l}1438 * * * \\
(0,005)\end{array}$ & $\begin{array}{l}1168 \\
(0,359)\end{array}$ & $\begin{array}{l}1910 * * * \\
(0,099)\end{array}$ & $\begin{array}{l}0,546 * * \\
(0,124)\end{array}$ & $\begin{array}{l}2887 * * * \\
(0,000)\end{array}$ \\
\hline $\begin{array}{l}\text { High Skilled (Social Capital) } \\
\text { Migrant }\end{array}$ & & $\begin{array}{l}1890 * \\
(0,008)\end{array}$ & & & & & \\
\hline High Skilled Migrant / Rest of & the world & & & $\begin{array}{l}2757 \\
(0,208)\end{array}$ & & & \\
\hline High Skilled SAM & & & & $\begin{array}{l}1728 * \\
(0,046)\end{array}$ & $\begin{array}{l}0,638 * * * \\
(0,395)\end{array}$ & $\begin{array}{l}1514 * * * \\
(0,437)\end{array}$ & \\
\hline High-skilled & $\begin{array}{l}0,846 * * * \\
(0,000)\end{array}$ & $\begin{array}{l}0,846^{* * * *} \\
(0,000)\end{array}$ & $\begin{array}{l}0,844 * * * \\
(0,000)\end{array}$ & $\begin{array}{l}0,845 * * * \\
(0,000)\end{array}$ & $\begin{array}{l}2480 * * * \\
(0,000)\end{array}$ & $\begin{array}{l}0,384 * * * \\
(0,000)\end{array}$ & $\begin{array}{l}0,819 * \\
(0,089)\end{array}$ \\
\hline Knowing other Entrepreneurs & $\begin{array}{l}2546^{* * * *} \\
(0,000)\end{array}$ & $\begin{array}{l}2490 * * * \\
(0,000)\end{array}$ & $\begin{array}{l}2536^{* * * *} \\
(0,000)\end{array}$ & $\begin{array}{l}2490 * * * \\
(0,000)\end{array}$ & $\begin{array}{l}1591 \text { *** } \\
(0,000)\end{array}$ & $\begin{array}{l}0,608 * * * \\
(0,000)\end{array}$ & $\begin{array}{l}0,701 * * * \\
(0,001)\end{array}$ \\
\hline Log GDP region & $\begin{array}{l}0,909 \\
(0,105)\end{array}$ & $\begin{array}{l}0,910 \\
(0,113)\end{array}$ & $\begin{array}{l}0,911 \\
(0,115)\end{array}$ & $\begin{array}{l}0,911 \\
(0,117)\end{array}$ & $\begin{array}{l}1230^{*} \\
(0,074)\end{array}$ & $\begin{array}{l}0,852 \\
(0,170)\end{array}$ & $\begin{array}{l}1489 * * * \\
(0,006)\end{array}$ \\
\hline Opportunity Recognition & $\begin{array}{l}1207 * * * \\
(0,000)\end{array}$ & $\begin{array}{l}1210 * * * \\
(0,000)\end{array}$ & $\begin{array}{l}1212^{* * *} \\
(0,000)\end{array}$ & $\begin{array}{l}1215 * * * \\
(0,000)\end{array}$ & $\begin{array}{l}1777 * * * \\
(0,000)\end{array}$ & $\begin{array}{l}0,540 * * * \\
(0,000)\end{array}$ & $\begin{array}{l}1185 \\
(0,127)\end{array}$ \\
\hline Female & $\begin{array}{l}0,729 * * * \\
(0,000)\end{array}$ & $\begin{array}{l}0,729 * * * \\
(0,000)\end{array}$ & $\begin{array}{l}0,732 * * * \\
(0,000)\end{array}$ & $\begin{array}{l}0,732 * * * \\
(0,000)\end{array}$ & $\begin{array}{l}0,592 * * * \\
(0,000)\end{array}$ & $\begin{array}{l}1636^{* * * *} \\
(0,000)\end{array}$ & $\begin{array}{l}0,694 * * * \\
(0,001)\end{array}$ \\
\hline Self-Efficacy & $\begin{array}{l}3692 * * * \\
(0,000)\end{array}$ & $\begin{array}{l}3700 * * * \\
(0,000)\end{array}$ & $\begin{array}{l}3705 \text { *** } \\
(0,000)\end{array}$ & $\begin{array}{l}3705 * * * \\
(0,000)\end{array}$ & $\begin{array}{l}1037 \\
(0,758)\end{array}$ & $\begin{array}{l}1004 \\
(0,972)\end{array}$ & $\begin{array}{l}1004 \\
(0,981)\end{array}$ \\
\hline Fear of Failure & $\begin{array}{l}0,686^{* * * *} \\
(0,000)\end{array}$ & $\begin{array}{l}0,685^{* * * *} \\
(0,000)\end{array}$ & $\begin{array}{l}0,685 * * * \\
(0,000)\end{array}$ & $\begin{array}{l}0,685 * * * \\
(0,000)\end{array}$ & $\begin{array}{l}0,785 \text { ** } \\
(0,012)\end{array}$ & $\begin{array}{l}1276^{* *} \\
(0,013)\end{array}$ & $\begin{array}{l}0,663 * * * \\
(0,004)\end{array}$ \\
\hline Age & $\begin{array}{l}1125^{* * *} \\
(0,000)\end{array}$ & $\begin{array}{l}1125 * * * \\
(0,000)\end{array}$ & $\begin{array}{l}1125 \text { *** } \\
(0,000)\end{array}$ & $\begin{array}{l}1125^{* * *} \\
(0,000)\end{array}$ & $\begin{array}{l}0,941 * * \\
(0,012)\end{array}$ & $\begin{array}{l}1072 * * * \\
(0,005)\end{array}$ & $\begin{array}{l}1021 \\
(0,495)\end{array}$ \\
\hline Age Squared & $\begin{array}{l}0,998 * * * \\
(0,000)\end{array}$ & $\begin{array}{l}0,998^{* * *} * \\
(0,000)\end{array}$ & $\begin{array}{l}0,998^{* * * *} \\
(0,000)\end{array}$ & $\begin{array}{l}0,998 * * * \\
(0,000)\end{array}$ & $\begin{array}{l}1000 \\
(0,158)\end{array}$ & $\begin{array}{l}0,999 * \\
(0,082)\end{array}$ & $\begin{array}{l}1000 \\
(0,632)\end{array}$ \\
\hline Dummy year & $\begin{array}{l}0,798 * * * \\
(0,000)\end{array}$ & $\begin{array}{l}0,800 * * * \\
(0,000)\end{array}$ & $\begin{array}{l}0,798 * * * \\
(0,000)\end{array}$ & $\begin{array}{l}0,800 \text { *** } \\
(0,000)\end{array}$ & $\begin{array}{l}0,836^{* *} \\
(0,031)\end{array}$ & $\begin{array}{l}1188^{*} \\
(0,041)\end{array}$ & $\begin{array}{l}0,908 \\
(0,367)\end{array}$ \\
\hline Constant & $\begin{array}{l}0,042 * * * \\
(0,000)\end{array}$ & $\begin{array}{l}0,041^{* * *} \\
(0,000)\end{array}$ & $\begin{array}{l}0,041^{* * *} \\
(0,000)\end{array}$ & $\begin{array}{l}0,041 \text { *** } \\
(0,000)\end{array}$ & $\begin{array}{l}1598 \\
(0,676)\end{array}$ & $\begin{array}{l}0,349 \\
(0,355)\end{array}$ & $\begin{array}{l}0,004 * * * \\
(0,000)\end{array}$ \\
\hline Adjusted R2 & 0,131 & 0,131 & 0,131 & 0,132 & 0,086 & 0,089 & 0,029 \\
\hline
\end{tabular}

$* * * \mathrm{p}<0.01, * * \mathrm{p}<0.05, * \mathrm{p}<0.1$ 
discussion issues beyond the scope of a quantitative analysis. This is why our future line of research includes a qualitative analysis, in order to explore more deeply the nonobservable factors that impact the decision of becoming an entrepreneur.

\section{Conclusions}

Our study focuses on the phenomenon of migrant entrepreneurship in and from emerging economies. Specifically, we studied the individual/environmental selection/ discrimination effects that determine the propensity for becoming an entrepreneur, as well as the quality and international orientation of those entrepreneurial initiatives. We identified human capital (individual) and dynamic regions (environmental) as the key selection/discrimination conditions in host emerging economies. By applying diverse theoretical approaches, our new insights from the context of migrant entrepreneurship may open the way for future studies to explore international migrations from and in emerging economies.

Acknowledgements Authors acknowledgement the financial support received by the Dirección de Investigación Universidad del Desarrollo, FI 2018.

Open Access This article is licensed under a Creative Commons Attribution 4.0 International License, which permits use, sharing, adaptation, distribution and reproduction in any medium or format, as long as you give appropriate credit to the original author(s) and the source, provide a link to the Creative Commons licence, and indicate if changes were made. The images or other third party material in this article are included in the article's Creative Commons licence, unless indicated otherwise in a credit line to the material. If material is not included in the article's Creative Commons licence and your intended use is not permitted by statutory regulation or exceeds the permitted use, you will need to obtain permission directly from the copyright holder. To view a copy of this licence, visit http://creativecommons.org/licenses/by/4.0/.

\section{References}

Acs, Z. (2006). How is entrepreneurship good for economic growth? Innovations, 1(1), 97-107.

Acs, Z. J., Braunerhjelm, P., Audretsch, D. B., \& Carlsson, B. (2009). The knowledge spillover theory of entrepreneurship. Small Business Economics, 32(1), 15-30.

Amoros, J., \& Bosma, N. (2014). Global Entrepreneurship Monitor 2013 Executive Report. US, MA: Babson College, Babson Park, Chile, Santiago: Universidad del Desarrollo, Malaysia, Kuala Lampur, Universiti Tun Abdul Razak.

Anderson S. \& Platzer M. (2006) American made: the impact of immigrant entrepreneurs and professional on U.S. Competitiveness. National Venture Capital Associate Report.

Ardichvili, A., Cardozo, R., \& Ray, S. (2003). A theory of entrepreneurial opportunity identification and development. Journal of Business Venturing, 18(1), 105-123.

Arenius, P., \& Minniti, M. (2005). Perceptual variables and nascent entrepreneurship. Small Business Economics, 24(3), 233-247.

Audretsch, D. B., Belitski, M., \& Desai, S. (2018). National business regulations and city entrepreneurship in Europe: a multilevel nested analysis. Entrepreneurship Theory and Practice, 1042258718774916.

Autio, E., \& Acs, Z. (2010). Intellectual property protection and the formation of entrepreneurial growth aspirations. Strategic Entrepreneurship Journal, 4(3), 234-251.

Bagwell, S. (2018). From mixed embeddedness to transnational mixed embeddedness: an exploration of Vietnamese businesses in London. International Journal of Entrepreneurial Behavior \& Research, 24(1), $104-120$. 
Baron, R. A., \& Tang, J. (2011). The role of entrepreneurs in firm-level innovation: joint effects of positive affect, creativity, and environmental dynamism. Journal of Business Venturing, 26(1), 49-60.

Becker, G. S. (1985). Human capital, effort, and the sexual division of labor. Journal of labor economics, 3(1, Part 2), S33-S58.

Belda, P. R., \& Cabrer-Borrás, B. (2018). Necessity and opportunity entrepreneurs: survival factors. International Entrepreneurship and Management Journal, 14(2), 249-264.

Biavaschi, C., Facchini, G., Mayda, A. M., \& Mendola, M. (2018). South-south migration and the labor market: evidence from South Africa. Journal of Economic Geography, 18(4), 823-853.

Bosma, N. (2013). The Global Entrepreneurship Monitor (GEM) and its impact on entrepreneurship research. Foundations and Trends in Entrepreneurship, 9(2), 143-248.

Bosma, N., Acs, Z. J., Autio, E., Coduras, A., \& Levie, J. (2008). Global entrepreneurship monitor. Executive report. London: Global Entrepreneurship Monitor.

Brenes, E. R., Ciravegna, L., \& Pichardo, C. A. (2018). Managing institutional voids: a configurational approach to understanding high performance antecedents. Journal of Business Research, 105, 345-358. https://doi.org/10.1016/j.jbusres.2018.03.022.

Bruton, G. D., Ahlstrom, D., \& Obloj, K. (2008). Entrepreneurship in emerging economies: where are we today and where should the research go in the future. Entrepreneurship Theory and Practice, 32(1), 1-14.

Carlsson, B., \& Jacobson, S. (1997). Diversity creation and technological systems: A technology policy perspective. In C. Edquist (Ed.), Systems of innovation (pp. 266-294). London: Pinter.

Chaganti, R. R. S., Watts, A. D., Chaganti, R., \& Zimmerman-Treichel, M. (2008). Ethnic-immigrants in founding teams: effects on prospector strategy and performance in new internet ventures. Journal of Business Venturing, 23(1), 113-139.

Charles, K. K., Hurst, E., \& Notowidigdo, M. J. (2018). Housing booms and busts, labor market opportunities, and college attendance. American Economic Review, 108(10), 2947-2994.

Chowdhury, F., Audretsch, D. B., \& Belitski, M. (2018). Institutions and entrepreneurship quality. Entrepreneurship Theory and Practice. https://oi.org/10.1177/1042258718780431.

Chreim, S., Spence, M., Crick, D., \& Liao, X. (2018). Review of female immigrant entrepreneurship research: past findings, gaps and ways forward. European Management Journal, 36, 210-222.

Clark, K., \& Drinkwater, S. (2000). Pushed out or pulled in? Self-employment among ethnic minorities in England and Wales. Labour Economics, 7(5), 603-628.

Clark, K., \& Drinkwater, S. (2016). Self-employment amongst migrant groups: new evidence from England and Wales. Small Business Economics, 48(4), 1047-1069. https://doi.org/10.2785/13779.

Clark, K., Drinkwater, S., \& Robinson, C. (2017). Self-employment amongst migrant groups: new evidence from England and Wales. Small Business Economics, 48(4), 1047-1069.

Clemens, M. A., Lewis, E. G., \& Postel, H. M. (2018). Immigration restrictions as active labor market policy: evidence from the mexican bracero exclusion. American Economic Review, 108(6), 1468-1487.

Colakoglu, S., Yunlu, D. G., \& Arman, G. (2018). High-skilled female immigrants: Career strategies and experiences. Journal of Global Mobility, 6(3/4), 258-284. https://doi.org/10.1108/JGM-10-2017-0039.

Constant, A., \& Zimmermann, K. F. (2006). The making of entrepreneurs in Germany: are native men and immigrants alike? Small Business Economics, 26(3), 279-300.

Crecente-Romero, F., Giménez-Baldazo, M., \& Rivera-Galicia, L. F. (2018). Can entrepreneurship channel overqualification in young university graduates in the European Union? Journal of Business Research, $89,223-228$.

Davidsson, P., \& Honig, B. (2003). The role of social and human capital among nascent entrepreneurs. Journal of Business Venturing, 18(3), 301-331.

Departamento de Extranjería y Migración. (2017). Estadístias Migratorias. Retrieved July 9, 2019 from: http:// www.extranjeria.gob.cl/media/2017/07/AnuarioEstadisticoNacionalDEM2015.pdf.

Dheer, R. J. (2018). Entrepreneurship by immigrants: a review of existing literature and directions for future research. International Entrepreneurship and Management Journal, 14(3), 555-614.

Drori, I., Honig, B., \& Wright, M. (2009). Transnational entrepreneurship: an emergent field of study. Entrepreneurship Theory and Practice, 33(5), 1001-1022.

Elo, M., Sandberg, S., Servais, P., Basco, R., Cruz, A. D., Riddle, L., \& Täube, F. (2018). Advancing the views on migrant and diaspora entrepreneurs in international entrepreneurship. Journal of International Entrepreneurship, 16(2), 119-133.

Estrin, S., Mickiewicz, T., \& Stephan, U. (2013). Entrepreneurship, social capital, and institutions: social and commercial entrepreneurship across nations. Entrepreneurship Theory and Practice, 37(3), 479-504.

Fairchild, G. B. (2010). Intergenerational ethnic enclave influences on the likelihood of being self-employed. Journal of Business Venturing, 25(3), 290-304. 
Fairlie, R. W., \& Lofstrom, M. (2015). Immigration and entrepreneurship. CESifo Working Paper Series No. 5298. Retrieved July 9, 2019 from: https://ssrn.com/abstract=259799.

Fairlie, R. W., Zissimopoulos, J. \& Krashinsky, H. (2010). The international Asian business success story? A comparison of Chinese, Indian and other Asian businesses in the United States, Canada and United Kingdom. In International differences in entrepreneurship (pp. 179-208). University of Chicago Press.

Fitzgerald, J., Leblang, D., \& Teets, J. C. (2014). Defying the law of gravity: the political economy of international migration. World Politics, 66, 406-445. https://doi.org/10.1017/S0043887114000112.

Florida, R. (2002). The Rise of the Creative Class-Revisited: Revised and Expanded. New York: Basic books (AZ).

Giest, S. (2017). Overcoming the failure of 'silicon somewheres': learning in policy transfer processes. Policy \& Politics, 45(1), 39-54. Chicago.

Gold, S. J. (1992). The employment potential of refugee entrepreneurship: Soviet Jews and Vietnamese in California. Review of Policy Research, 11(2), 176-186.

Grau, A. J. G., \& López, F. R. (2018). Determinants of migratory flow in Europe: A fuzzy-set approach. Journal of Business Research. https://doi.org/10.1016/j.jbusres.2018.01.051.

Griffin-EL, E. W., \& Olabisi, J. (2018). Breaking boundaries: Exploring the process of intersective market activity of immigrant entrepreneurship in the context of high economic inequality. Journal of Management Studies, 55(3), 457-485.

Guerrero, M., \& Urbano, D. (2020). Institutional conditions and social innovations in emerging economies: insights from Mexican enterprises' initiatives for protecting/preventing the effect of violent events. The Journal of Technology Transfer, 45(4), 929-957.

Guerrero, M. (2020). Does workforce diversity matter on corporate venturing? Economics of Innovation and New Technology. https://doi.org/10.1080/10438599.2020.1843989.

Guerrero, M., Liñán, F., \& Cáceres-Carrasco, F. R. (2020). The influence of ecosystems on the entrepreneurship process: a comparison across developed and developing economies. Small Business Economics. https://doi.org/10.1007/s11187-020-00392-2.

Hart, D. M., \& Acs, Z. J. (2011). High-tech immigrant entrepreneurship in the United States. Economic Development Quarterly, 25(2), 116-129.

He, X., Brouthers, K. D., \& Filatotchev, I. (2018). Market orientation and export performance: the moderation of channel and institutional distance. International Marketing Review, 35(2), 258-279.

Huang, S. (2012). Taiwanese Entrepreneurs Saying Goodbye to the U.S., Hello to China. Forbes.

John, M. (2019). Venezuelan economic crisis: crossing Latin American and Caribbean borders. Migration and Development, 8(3), 437-447.

Kenney, M. (2017) "Explaining the growth and globalization of Silicon Valley: the past and today". Berkeley Roundtable on the International Economy (BRIE) Working Paper 2017-1.

Kerr, S. P., \& Kerr, W. R. (2020). Immigrant entrepreneurship in America: Evidence from the survey of business owners 2007 \& 2012. Research Policy, 49(3), 103918.

Kloosterman, R. C. (2010). Matching opportunities with resources: A framework for analysing (migrant) entrepreneurship from a mixed embeddedness perspective. Entrepreneurship and Regional Development, $22(1), 25-45$.

Kloosterman, R., \& Rath, J. (2001). Immigrant entrepreneurs in advanced economies: Mixed embeddedness further explored. Journal of Ethnic and Migration Studies, 27(2), 189-201.

Kochhar, R. (2015). Three-in-Ten U.S. Jobs Are Held by the Self-Employed and the Workers They Hire: Hiring More Prevalent Among Self-Employed Asians, Whites and Men. Washington, D.C.: Pew Research Center.

Krieger, T., Renner, L., \& Ruhose, J. (2018). Long-term relatedness between countries and international migrant selection. Journal of International Economics, 113, 35-54.

Kwon, S. W., \& Arenius, P. (2010). Nations of entrepreneurs: A social capital perspective. Journal of Business Venturing, 25(3), 315-330.

Levesque, M., \& Minniti, M. (2006). The effect of aging on entrepreneurial behavior. Journal of Business Venturing, 21(2), 177-194.

Levie, J. (2007). Immigration, in-migration, ethnicity and entrepreneurship in the United Kingdom. Small Business Economics, 28(2), 143-169.

Lin, D., Zheng, W., Lu, J., Liu, X., \& Wright, M. (2018). Forgotten or not? Home country embeddedness and returnee entrepreneurship. Journal of World Business, 54, 1-13. https://doi.org/10.1016/j.jwb.2018.08. 003.

Liu, C. Y., Ye, L., \& Feng, B. (2019). Migrant entrepreneurship in China: Entrepreneurial transition and firm performance. Small Business Economics, 52(3), 681-696. 
Mandakovic, V., Cohen, B., \& Amorós, J. E. (2015). Entrepreneurship policy and its impact on the cultural legitimacy for entrepreneurship in a developing country context. In Entrepreneurship, Regional Development and Culture (pp. 109-125). Berlin: Springer International Publishing.

Manev, I. M., \& Manolova, T. S. (2010). Entrepreneurship in transitional economies: Review and integration of two decades of research. Journal of Developmental Entrepreneurship, 15(01), 69-99.

Marvel, M. R., Davis, J. L., \& Sproul, C. R. (2016). Human capital and entrepreneurship research: A critical review and future directions. Entrepreneurship Theory and Practice, 40(3), 599-626.

Massón-Guerra, J. L., \& Ortín-Ángel, P. (2017). Regional entrepreneurship capital and firm production. Small Business Economics, 49(3), 595-607.

Massón-Guerra, J. L., \& Ortín-Ángel, P. (2019). Entrepreneurship capital spillovers at the local level. Small Business Economics, 52, 175-191. https://doi.org/10.1007/s11187-018-0014-8.

McGovern, P. (2012). Inequalities in the (De-) commodification of labour: immigration, the nation state, and labour market stratification. Sociology Compass, 6(6), 485-498.

Moghaddam, K., Rustambekov, E., Weber, T., \& Azarpanah, S. (2018). Transnational entrepreneurship, social networks, and institutional distance: toward a theoretical framework. New England Journal of Entrepreneurship, 21(1), 45-64.

Monti, D. J., Smith-Doerr, L., \& MacQuaid, J. (2007). Immigrant entrepreneurs in the Massachusetts biotechnology industry. Boston: Immigrant Learning Center.

Morgan, H., Sui, S., \& Baum, M. (2017). Are SMEs with immigrant owners exceptional exporters?. In Academy of Management Proceedings (Vol. 2017, No. 1, p. 10027). Academy of Management.

Naudé, W., Siegel, M., \& Marchand, K. (2017). Migration, entrepreneurship and development: a critical review. IZA Journal of Migration., 6(5). https://doi.org/10.1186/S40176-016-0077-8.

Neville, F., Orser, B., Riding, A., \& Jung, O. (2014). Do young firms owned by recent immigrants outperform other young firms? Journal of Business Venturing, 29(1), 55-71.

Nontenja, N., \& Kollamparambil, U. (2018). Self-selection in migration between developing countries: the role of unobservable skills of Gauteng's migrant population. International Migration, 56, 167-189.

O'brien, R. M. (2007). A caution regarding rules of thumb for variance inflation factors. Quality \& Quantity, 41(5), 673-690.

Paulson, A. L., \& Townsend, R. (2004). Entrepreneurship and financial constraints in Thailand. Journal of Corporate Finance, 10(2), 229-262.

Peroni, C., Riillo, C. A., \& Sarracino, F. (2016). Entrepreneurship and immigration: evidence from GEM Luxembourg. Small Business Economics, 46(4), 639-656.

Pruthi, S., \& Mitra, J. (2018). Journal of entrepreneurship and innovation in emerging economies: Special issue on 'migrant and transnational entrepreneurs: International entrepreneurship and emerging economies'. Journal of Entrepreneurship and Innovation in Emerging Economies, 4(1), 93-99.

Reynolds, P., Bosma, N., Autio, E., Hunt, S., De Bono, N., Servais, I., \& Chin, N. (2005). Global entrepreneurship monitor: data collection design and implementation 1998-2003. Small Business Economics, 24(3), 205-231.

Riddle, L., \& Brinkerhoff, J. (2011). Diaspora entrepreneurs as institutional change agents: the case of Thamel. com. International Business Review, 20(6), 670-680.

Riddle, L., Hrivnak, G. A., \& Nielsen, T. M. (2010). Transnational diaspora entrepreneurship in emerging markets: bridging institutional divides. Journal of International Management, 16(4), 398-411.

Roland Xavier, S., Kelley, D., Kew, J., Herrington, M., \& Vorderwülbecke, A. (2013). Global entrepreneurship monitor 2012. Global Report.

Sahasranamam, S., \& Nandakumar, M. K. (2018). Individual capital and social entrepreneurship: role of formal institutions. Journal of Business Research, 107, 104-117. https://doi.org/10.1016/j.jbusres.2018. 09.005 .

Sahin, M., Nijkamp, P., \& Baycan-Levent, T. (2007). Migrant entrepreneurship from the perspective of cultural diversity. In L.-P. Dana (Ed.), Handbook of research on ethnic minority entrepreneurship (pp. 99-116). Northampton/Cheltenham: Edward Elgar Publishing.

Sandberg, S., Immonen, R., \& Kok, S. (2018). Refugee entrepreneurship: taking a social network view on immigrants with refugee backgrounds starting transnational businesses in Sweden. International Journal of Entrepreneurship and Small Business, 36, 1. https://doi.org/10.1504/ijesb.2019.10008915.

Saridakis, G., Idris, B., Hansen, J. M., \& Dana, L. P. (2019). SMEs' internationalisation: When does innovation matter? Journal of Business Research, 96, 250-263.

Simón-Moya, V., Revuelto-Taboada, L., \& Guerrero, R. F. (2014). Institutional and economic drivers of entrepreneurship: an international perspective. Journal of Business Research, 67(5), 715-721.

Skeldon, R. (2012). China: An emerging destination for economic migration. Migration Information Source. Washington: Migration Policy Institute. 
Stephan, P. E., \& Levin, S. G. (2001). Exceptional contributions to US science by the foreign-born and foreign-educated. Population Research and Policy Review, 20(1), 59-79.

Stephan, U., Uhlaner, L. M., \& Stride, C. (2015). Institutions and social entrepreneurship: the role of institutional voids, institutional support, and institutional configurations. Journal of International Business Studies, 46(3), 308-331.

Sui, S., Morgan, H. M., \& Baum, M. (2015). Internationalization of immigrant-owned SMEs: the role of language. Journal of World Business, 50(4), 804-814.

Terjesen, S., \& Elam, A. (2009). Transnational entrepreneurs' venture internationalization strategies: a practice theory approach. Entrepreneurship Theory and Practice, 33(5), 1093-1120.

Vandor, P., \& Franke, N. (2016a). Why are immigrants more entrepreneurial? Harvard Business Review. Retrieved July 9, 2019 from: https://hbr.org/2016/10/why-are-immigrants-more-entrepreneurial.

Vandor, P., \& Franke, N. (2016b). See Paris and... found a business? The impact of cross-cultural experience on opportunity recognition capabilities. Journal of Business Venturing, 31(4), 388-407.

Verbeke, A., \& Ciravegna, L. (2018). International entrepreneurship research versus international business research: a false dichotomy? Journal of International Business Studies, 49(4), 387-394.

Wadhwa, V., Saxenian, A., Rissing, B. A., \& Gereffi, G. (2007) America's new immigrant entrepreneurs: Part I. Duke Science, Technology \& Innovation, Paper No. 23. Available at: https://doi.org/10.2139/ssrn. 990152.

Wadhwa, V., Saxenian, A., Rissing, B. A., \& Gereffi, G. (2008). Skilled immigration and economic growth. Applied Research in Economic Development, 5(1), 6-14.

Waldinger, R. D., Aldrich, H., \& Ward, R. (1990). Ethnic entrepreneurs: Immigrant business in industrial societies (Vol. 1). New York: Sage Publications, Inc..

Welter, F. (2011). Contextualizing entrepreneurship-Conceptual challenges and ways forward. Entrepreneurship Theory and Practice, 35(1), 165-184.

Publisher's note Springer Nature remains neutral with regard to jurisdictional claims in published maps and institutional affiliations.

\section{Affiliations}

\section{Maribel Guerrero ${ }^{1,2,3} \cdot$ Vesna Mandakovic $^{1} \cdot$ Mauricio Apablaza ${ }^{4}$. Veronica Arriagada $^{5}$}

1 School of Business and Economics, Universidad del Desarrollo, Av. Plaza 680, Las Condes, Santiago, Chile

2 Northumbria Centre for Innovation Regional Transformation and Entrepreneurship (iNCITE), Newcastle Business School, Northumbria University, Sutherland Building, 2 Ellison PI, Newcastle upon Tyne, UK

3 Centre for Innovation Research (CIRCLE), Lund University, Sölvegatan 16, Lund, Sweden

4 School of Government, Universidad del Desarrollo, Av. Plaza 680, Las Condes, Santiago, Chile

5 Centre for Social Conflict and Cohesion (COES), Diagonal Paraguay 257, Torre 26, Of. 1504, Santiago, Chile 